\title{
Driving up Standards: Civil Service Management and Decentralization: Case Study of Uganda
}

Commonwealth Journal of Local Governance Issue 11: December 2012 http:/lepress.lib.uts.edu.au/ojs/index.php/cjlg

\author{
Lazarus Nabaho \\ Uganda Management Institute \\ Kampala \\ Uganda
}

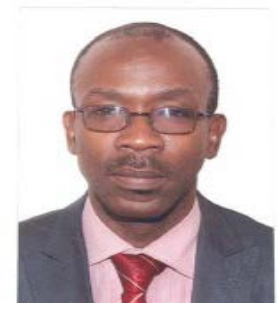

\begin{abstract}
There is a consensus that decentralization by devolution leads to improved service delivery, but debate on the appropriate type of personnel arrangements for delivering decentralized services is far from over. Put differently, the discourse on whether civil service management should be decentralized or devolved still rages on. Little wonder that countries which started off with decentralized civil service management models in the 1990s are currently centralizing some aspects of personnel management while others are having centralized and decentralized personnel arrangements operating side by side in sub-national governments. The paper argues that civil service management should be decentralized whenever a country chooses the path of decentralization by devolution. Using Uganda's example, the paper highlights two major challenges of managing the civil service under separate personnel arrangements: civil service appointments devoid of merit, and the perennial failure to attract and retain qualified human resource. The paper presents proposals on how to ensure meritocracy in appointments and how to bolster attraction and retention of human capital in local governments.
\end{abstract}

Key words: Civil service, personnel systems, local governments

\section{Introduction}

The aim of the paper is to explore the degree to which local governments in Uganda comply with standards pertaining to recruitment and selection of civil servants; and the implications of local governments' level of compliance with recruitment and selection standards on good governance, bureaucratic capability and service delivery. Based on the findings, the paper makes recommendations aimed at ensuring adherence to recruitment and selection standards enshrined in the existing legal and policy frameworks. Data for the paper was collected by conducting in-depth interviews with three long serving district chief executive officers (chief administrative officers) in March 2010. Secondary data was collected by reviewing newspapers, government report and research reports. Content analysis technique was used to analyse the data. 


\section{Personnel systems in local governments}

The literature suggests that decentralization is a spectrum rather than a single state, ranging from deconcentration to delegation to devolution. Key features of the civil service tend to vary with the degree of administrative decentralization. When a country chooses deconcentration, provider staff working at local level are employees of and accountable to the centre, usually through their respective ministries. Under decentralization by delegation providers could be employees of central or local government, but the centre typically defines pay and employment conditions. With devolution, providers are employees of local government but the central government may establish standards and procedures for hiring and managing staff (World Bank, 2003). However, even with decentralization by devolution, some African states have opted for a centralized civil service management system or a largely decentralized civil service management system, operating side by side with a centralized or unified system for top public servants.

Conceptually, there are three types of personnel systems for managing providers of decentralized services: integrated personnel system, unified personnel system and separate personnel system.

In an integrated personnel system, local government is composed of central government civil servants (Lubanga, 1998: 69). The personnel of the central government and that of local government form part of the same service and transfers are possible both between local governments and to departments of central government (Maheshwari, 2011: 54). The system implies 'deconcentration' rather than 'devolution' of the civil service. One of the noticeable features of the integrated personnel system is that the dichotomy between central government cadres and those of local government is non-existent. Central government appoints and posts officers to local authorities to meet service delivery needs from the central pool.

Various arguments have been advanced in favour of retaining the management of human resources at central government level. Crucial is the need to enforce minimum standards of qualifications for staff which for some services, such as education and health, particularly important (Aslam et al, 2010). Green (2005) has identified additional arguments for central government involvement in staffing matters at local government level. First, keeping local civil services under the umbrella of central discretion can ensure some standardization in working conditions across the country. Without this, local governments in poorer and remote areas may find it an uphill task to compete against richer areas and national coverage of public services may suffer. Second, central government involvement in staffing may expand civil servants' career paths by opening channels between local and central employment. 
Public choice theory advances additional reasons for reluctance of the central government to grant local government autonomy in the management of human resources. Granting administrative autonomy to local governments in recruitment and management of staff means reallocation of jobs and consequently power, geographically and institutionally. In this regard, bureaucracies and power holders in the status quo, prior to decentralization, tend to resist human resource management reforms as they stand to lose prestige. This resistance is particularly pronounced where bureaucracies remain with the central executive and political allegiances.

Central authorities may also see decentralization as an opportunity to appoint a dependable and proven individual who will 'tow the party line' and design and implement reforms according to national political interests rather than local ones. Jobs are an efficient medium for distribution of patronage (World Bank, 2009; Aslam et al, 2010). The integrated personnel arrangement is demonized by sub-national governments because it leads directly to control from central government and occasions a split between loyalties of senior officials managing decentralized services: their 'operational' loyalty to local councils and their 'career' loyalty to central masters. If he/she has any ambition for his/her future, no officer is likely to defend the council's interests where they clash with the ideas of a minister or central government. In addition, centralized structures are inherently incapable of satisfying local needs since; rarely do incentives exist for central government officials to perceive citizens as their clientele (Lubanga, 1998: 70).

In a separate personnel system, each local government acts as a completely autonomous employer (Mawhood, 1983). In principle, each local government appoints and administers personnel who are not automatically transferable to another jurisdiction (Maheshwari, 2011). The separate personnel framework is preferred under decentralization by devolution because:

(a) It keeps the employees' loyalty unidirectional, that is, the employees' loyalty is to the local government that has the right to hire and fire them.

(b) Staff appointed locally would give quicker feedback opportunity and articulation since they are appointed to meet their employer's developmental needs, and proximity would; therefore make them more responsive and accountable to their constituents through the elected local leadership (Kakumba, 2008: 98). This is unlikely in integrated personnel systems where dual allegiance is the order of the day especially for senior officials. 
In the separate personnel system, some common arrangement is needed to support the merit principle and establish a link with standards that apply in the national civil service. This can be done by enacting national laws and developing regulations. In some cases, a separate personnel system does not imply that terms and conditions of service of local government employees are different from those of central government employees. For instance in Uganda, Section 61(1) of the Local Government Act (Cap 243) (GoU, 1997: 5345) harmonizes the terms and conditions of local government employees with those central government employees by stating that, 'The terms and conditions of service of local government staff shall conform to those prescribed by the Public Service Commission for the public service generally'. In some countries, terms and conditions of sub-national employees are different from those of central government bureaucrats. In Kenya, prior to the promulgation of the 2010 Constitution, the terms and conditions of local government civil servants were different from those of the central government and were negotiated between local governments and trade unions (Steffensen et al, 2004). The separate personnel system is often faulted for localizing civil servants and sealing their fate in a rather closed system where their career progress could be easily suffocated in one locality (Kakumba, 2008).

The unified personnel approach is a midway house between the extremes of integrated and separate personnel arrangements (Olowu, 2001:15). It is a personnel model in which some or all categories of personnel of local governments constitute a career service for the entire state (Maheshwari, 2005). In unified personnel arrangements, local government staff are employed locally but organized nationwide in a single civil service parallel to the central one (Mawhood, 1983). In typical unified systems, all local government civil servants are members of a national 'local government civil service’ and are only transferable between local governments.

Normally, a national body - a Local Government Service Commission - takes charge of the local government staff. The Local Government Service Commission (LGSC) does what the Public Service Commission (PSC) does for the national civil service. The rationale behind establishing an LGSC is to remove malpractice in civil service appointments that are inevitable under the separate personnel system. The weakness with the unified personnel system is that senior local government staff are treated as central government staff (Olowu, 2001). A unified personnel system inhibits local government autonomy. It further results in the accountability and loyalty of local government being to the appointing authority instead of the council (Sharma, 2010). 
As can be seen from the above, a separate personnel system is the most suitable arrangement for decentralization by devolution. It is superior to other personnel arrangements because it increases responsiveness, enhances the accountability of civil servants to elected leaders and overcomes challenges of dual allegiance by civil servants to central and local government masters. In practice, most African countries have two or more personnel systems operating side by side in local governments. In Uganda, local governments are administered under a largely separate personnel system and a partly an integrated one. In Malawi, senior management staff (District Commissioners and Directors) are appointed by the Local Government Service commission/Local Administration Service Committee (LACSOM) and serve under a unified personnel system.

\section{Uganda's local government personnel system}

The decentralization policy in Uganda was launched in October 1992 with the first 13 pilot districts (Kakumba, 2008). The enactment of the Local Government (Resistance Councils) Statute, 1993 was intended to give a firm legal basis for the decentralization policy. Following the coming into force of the 1995 Constitution, the decentralization policy covered the entire country. Local governments were empowered as focal points in managing development and social service delivery (Nsibambi, 1998:14). Number 11(iii) of national objectives and directive principles of state policy in the Constitution (1995:14) of Uganda states that,

The state shall be guided by the principles of decentralization and devolution of governmental functions and powers to the people at appropriate levels where they can best manage and direct their affairs.

Under Uganda's decentralization framework, the district is the highest level of local government. Below the district are lower local governments (municipalities, city divisions, town council and subcounties). The District Council is the highest political organ of local government and comprises the District Chairperson as the political head plus a number of councillors representing electoral areas of the district and interest groups. The Chief Administrative Officer (CAO) is the head of the district public service and also the accounting officer. The CAO is charged with implementing lawful council resolutions and central government decisions.

Uganda's decentralization experience is generally considered a success story in terms of its extent and impact (Ndegwa \& Levy, 2003). The transfer of staff hiring and firing decisions to the district governments through the District Service Commissions was considered to be one of the cornerstones of Ugandan decentralization reforms (Bossert \& Beauvais, 2002). Prior to civil service decentralization, local government officials were either seconded to local governments or placed in a unified personnel system for all local governments in the country (Olowu, 2001). 
With the onset of decentralization, civil servants posted to the districts were formally transferred to local governments and separate District Service Commissions were set up to manage human resources in districts and local administrations. The right of DSCs to hire, fire and oversee district staff was anchored in the new Constitution (1995) and further consolidated in the Local Government Act (1997). Article 200(1) of the Constitution of the Republic of Uganda (GoU 1995:101-102) and Sections 52 to 69 of the Local Government Act (Cap 243) (GoU, 1997: 5341-5350) provide the legal basis for a separate human resource management system whereby one District Service Commission (DSC) is constituted with a district-wide mandate to appoint persons to hold or act in any office in the service of the district or urban council, including the power to confirm appointments, to exercise disciplinary control over persons holding or acting in such offices and to remove those persons from office. Members of the DSC are appointed by the district council on the recommendation of the District Executive Committee, approval by central government's Public Service Commission, to hold office for a period of four years, and are eligible for appointment for one more term. A member of the DSC may be removed from office by the district council after consultation with the Public Service Commission on grounds of inability to perform, misbehavior, misconduct, or incompetence.

From 2006 - following a Constitutional amendment the previous year - Uganda has witnessed a wave of centralization of some elements of local government personnel administration. Presently, the power to hire and fire senior local government officials (Chief Administrative Officers, Deputy Chief Administrative Officers and Town Clerks of cities and municipalities) are in the hands of the central government's Public Service Commission. The goal of centralizing the high level administrators was to improve accountability and enhance the performance of local governments (Manyak \& Katono, 2010). It was further intended to make senior staff more effective than if they were working under the patronage of local politicians (IGG, 2008). The centralization of heads of administration in districts, cities and municipalities constitutes a more fundamental threat to decentralization by devolution since it has cut the accountability link between elected councils and higher local governments. Similarly, critics of centralization of top administrators in local governments argue that Uganda erred by solving administrative problems in local governments through centralization, and argue that centralization would result in a snowball effect, where local accountability mechanisms become totally undermined. The country is yet to see whether their predictions would come true. It can now be inferred that Uganda's local government personnel system is now manifested in a separate personnel type, but with some aspects of an integrated personnel system. 
While exercising their broad human resource management functions, DSCs are required to conform to standards established by the Public Service Commission for the Public Service generally. Section 58(1) of the Local Government Act (Cap 243) (GoU 1997: 5343) insulates the DSC from any external influence by unequivocally stating that, 'The District Service Commission shall be independent and shall not be subject to control or direction of any person or authority'. Section 56(1) [a]-[d] spells out the minimum qualifications for a member of the DSC: being ordinarily a resident of the district; being a person of high moral character and proven integrity; possessing a minimum of ten years working experience in a responsible position; and being in possession of a diploma qualification.

Article 166(1) [d] and [e] gives the Public Service Commission the mandate to guide, coordinate and regulate the of the DSCs. Section 59(2) of the Local Government Act provides for people aggrieved by decisions of the DSCs to appeal to the PSC. When one decides to appeal against the decision of the DSC to the PSC, then decision of the latter remains until the PSC has ruled over the matter.

\section{Challenges of managing local government staffing}

Local governments in Uganda experience several challenges in managing human resources. These challenges can be placed in two broad categories: breach of merit in appointment to civil service posts and inability to attract and retain human capital. These challenges are discussed below.

\section{i) Breach of merit principles in recruitment in the district civil service}

Merit can simply be defined as appointment of the best person for any given job (United Nations, 2005; McCourt, 2007). The 'best person' definition implies the appointee is the best candidate; posts are open to all eligible candidates; and the appointment process is systematic, transparent and challengeable (McCourt, 2007: 3). The assumption fundamental to merit appointment is that the bureaucracy must be able to recruit the best possible personnel and in so doing promote effective government (Peters, 2001: 86-7). Lamentably, some local governments in Uganda practice meritbased recruitment and selection more in theory than in practice. The cases below lend credence this observation.

\section{Discriminatory hiring practices}

Hiring practices that discriminate against eligible candidates fall short of merit. There is evidence to suggest that DSCs display discriminatory tendencies during the hiring of staff. Rather than appoint staff 'for the district from the national labour market', some DSCs appoint staff 'for the district from the local/district labour market'. As a result, civil service ranks are filled with inept 'sons and daughters of the soil' (local home boys and girls). Some DSCs advertise vacancies in national 
newspapers to elicit responses from qualified candidates but the selection for vacant positions is usually from the local (district) labour markets. Recruiting sons and daughters of the soil is a major challenge of personnel decentralization in Uganda. One CAO said, 'job applicants from other districts are regarded persona non grata by DSCs'. In the National Integrity Survey of 2008, the Inspectorate of Government (IGG) found that DSCs had persistently chosen to recruit people from local areas and that the practice had limited opportunities for recruiting persons with relevant competences.

\section{Patronage appointments}

There is a strong perception that appointment in the district public service is based on patronage. In other words, 'technical know-who' rather than 'technical know-how' bolsters a candidate's chances of being appointed in the district civil service. District councils and individual elected leaders operate from a distance to influence the selection decisions of the DSCs. To illustrate the magnitude of the problem, one CAO said, '...the hand of the District Council is invisible and yet very powerful in almost every selection decision by the District Service Commissions'. These findings demonstrate that DSCs do not act independently of district councils, and corroborate findings from earlier studies. In Galiwango (2008: 209), one respondent (a senior civil servant in a district) is reported to have said:

It is difficult to get a job in the district unless the councillors have talked to the chairperson [of the DSC]. The DSC is just a rubber stamp

The findings are further consistent with Kakumba (2003) who concluded that DSCs in Uganda are externally influenced; and the Ministry of Public Service (2003: 3) that noted that 'District Service Commissions tended to appoint staff recommended by politicians'.

But what is it that sustains patronage in local governments? The single most important driver of patronage in recruitment and selection is the appointment arrangement for the DSC. As already pointed out, the DSC is virtually 'appointed' by the District Chairperson who presents names to the District Executive Committee that he/she appoints. None of the members of the executive can challenge the appointing authority (District Chairperson) for fear of being relieved of his/her duties. Asked about criteria district chairpersons consider to nominate persons to serve on the DSC, one respondent in Galiwango (2008:206) contended, thus:

One cannot be appointed to...the DSC unless one was a campaign agent of the ruling [district] chairperson. It has become one way of appeasement and entrenchment for incumbents. 
It therefore suffices to say that merit, more often than not, is not adhered to when appointing members of the DSC (Galiwango, 2008). The appointment arrangement devoid of merit means that members of the DSC must 'dance to the tune' of the appointing authority and/or local politicians. Hence, members of the DSC have tended to reciprocate to their appointing authority by offering jobs to relatives, friends and political supporters of members of the District Council. A member of the DSC is unlikely to secure a second term in office unless he/she has been serving the individual interests of local politicians in matters of recruitment and selection of civil servants. To bolster their chances of securing a second term in office, some members of the DSC have no option but to succumb to the pressures from the appointing authority. In some cases, nomination and eventual appointment to serve on the DSC is heavily premised on the likelihood of nominees to be pliable rather that on their ability to execute the functions of the office. Statutory requirements such as high moral character and proven integrity seem to take a back seat while District Councils are nominating and subsequently appointing persons to serve on the DSCs.

Second, the balkanization of the country into small and sometimes unviable tribal (ethnic) districts has promoted patronage in recruitment and selection. Uganda with a population of 33 million boasts of 112 district local governments and plans are underway to create 21 more district. Asked whether the creation of new districts exacerbates patronage in recruitment and selection, one CAO said, 'District are too small to the extent that almost everyone is related to the other'. This means that with a small district, it is easier to have a patron.

\section{Commercialization of entry level positions}

Widespread corruption in Uganda has not spared member of DSCs. To infer that in some local governments civil service jobs are on the counter would not constitute an overstatement. 'Buying' jobs in some local governments seems to be the norm rather than an exception. The Inspectorate General of Government (IGG), in exercising powers conferred upon him by the Constitution and the Inspectorate of Government Act (2002), has investigated a multitude of cases involving bribery in recruitment and selection and consequently recommended termination of some appointed local government bureaucrats.

In March 2010, the IGG ordered the Luweero District Service Commission to dismiss the town clerk of Wobulenzi town council over bribing the DSC to scoop a job! (The Daily Monitor, 19 March 2010). According to the IGG, several applicants were confidentially contacted by some people [members of the DSC] to solicit bribes and only those who pledged the biggest bribe were short listed for the interviews. The IGG further contended that following the bribery, Mr Ssebudde was the only 
person short listed for the post of town clerk and was automatically appointed. In this case, the major factor the DSC considered to offer the applicant a job was his ability to raise the highest bribe and not his ability to execute the functions of the office. In the New Vision 1 April 2010:10), the Regional Inspectorate Officer in the IGG's office, is quoted as saying that, ' In Amuru district, those who ask for jobs are told to pay bribes equal to three months salary of a civil servant'. Offering bribes by public servants to get jobs in local governments will exacerbate corruption in local government since public officers who offer bribes to get jobs start their service life with corruption and have the logic and motivation to engage in the same throughout. Once a person accepts to offer a bribe to get a job, it means that that person does not define corruption as morally wrong and has a high likelihood of engaging in any form of corruption.

\section{Breach of minimum job specifications /standards}

Other irregularities in the recruitment process in districts involve breach of minimum specifications for jobs. Every job in local government has a person specification to determine what kind of person is needed to perform the job effectively. These are minimum attributes, and not either average or maximum. Good human resource practice dictates that a person who does not meet the minimum requirements should not be considered for a job opening. District Service Commissions have blatantly breached minimum job specifications while short listing job applicants and making job offers. DSCs have made irregular appointments in the district public service prompting aggrieved parties to invoke Section 59 of the Local Government Act and appeal to the Public Service Commission.

Uganda's print media regularly reports cases where the PSC and the Inspectorate of Government have directed DSCs to rescind appointments of district staff over lack of minimum qualifications. In April 2010, the PSC ordered Abim District Service Commission to cancel the appointment of the District Education Officer (The New Vision 22 April 2010) and the appointment of five Mukono district employees over lack of required academic qualifications and experience (The New Vision 31 May 2010). The chairperson of Mukono District Service Commission, is quoted as saying that, 'those whose appointments would be cancelled because they lacked the academic qualifications at the time they got the jobs to re-apply when the jobs are re-advertised' (New Vision 31 May 2010. When a district appoints someone who does not meet the minimum specifications, then that may result in giving the public an inferior service. This trend needs to be reversed so as to improve service delivery in local governments. 
Breaching the merit principle is likely to have disastrous consequences on good governance and service delivery. There is no doubt that appointments based on patronage undermine the capacity of the bureaucracy; affect the integrity of the district civil service; and limit economic growth and therefore poverty reduction. Merit- based appointment has over time been associated with the quality and integrity of the civil service at various levels of government. It has been singled out as one of the major factors associated with low incidences of corruption in the implementing arm of government (World Bank, 1997: 16; United Nations, 2005: 80). It is being accepted in policy circles as an anticorruption strategy. Merit-based recruitment is further associated with economic growth. Bureaucracies with strong meritocratic tradition are associated with superior economic growth (Raunch \& Evans, 2000). The 'miracle' era in East Asia is attributed, in part, to meritocratic selection. On whether irregularities in appointment affect performance of the district, all the three CAO's answered in the affirmative. One of them said:

What would you expect? The input affects the output. If you accept to let garbage in, then be prepared for garbage out. We are currently having so many incompetent public servants owing to politicization of recruitment and selection.

The assertion of the CAO's corroborate Therkildsen and Tidemand (2007) who noted that districts in Uganda that upheld merit principles performed better than those that had not. Hence, differences in performance across local governments can partly be attributed to merit-based recruitment and selection.

\section{ii) Inability to attract and retain qualified staff}

Human capital in the form of qualified staff is one of the greatest assets to local governments. The availability of adequate and skilled human resources at the right time to carry out functions of local government is one of the key factors in the process of ensuring that service delivery takes place. Hence, attraction and retention of civil servants is integral to capacity and performance of local government (Jean et al, 2010). Local governments in Uganda face a perennial challenge of attracting and retaining adequate and skilled human resources. A number of local governments have unstaffed posts. Currently the staffing levels stand at $64.1 \%$ in urban authorities and $55.5 \%$ in the districts averaging at 59.8\% of the approved establishment across the board (Amooti, 2010: 8). According to the Ministerial Policy Statement for the Ministry of Local Government (2010: 38), strategic positions in local governments were staffed to an average of $58 \%$. The staffing gaps can be attributed to retention challenges and lack of resources to pay the appointees. Government now requires local governments to fill their establishments by $60 \%$ and provides financial resources for salaries. Several factors contribute to the failure by sub-national units to attract and retain staff, as follows. 


\section{Lack of autonomy over pay policy}

To be able to attract and retain qualified individuals, local governments must have something to offer through competitive pay and a range of other incentives. Local governments are conferred the powers to hire and fire; and set local incentives but have no autonomy to set policy. Central government imposes salary levels, benefits and employment conditions. Local governments are required to adhere to a unified national salary scale, which represents a major constraint on local decision space. Restricting local government autonomy in determining wage rates was intended to ensure some standardization in the working conditions across the country.

Low pay has contributed to the inability of local governments to attract and retain high quality staff. Few candidates are willing to work for available pay. Often, desirable civil servants are lured into private sector positions that provide more competitive salaries. Indeed, top performers are only able to commit a small number of years to local government service (Jean, et al, 2010). For instance, recently there has been an exodus of staff from local governments to well paying semi-autonomous government agencies and NGOs (Amooti, 2010: 8). Local governments can be rightly regarded as 'training grounds' for central government and the private sector. To counter retention challenges, some local governments use their discretionary powers to set local incentives. Kanungu district pays a top-up allowance of 500,000 shillings to doctors on top of their basic salary (Jean et al, 2010). Even if local governments were given autonomy to set wage rates, they would not afford to pay more than the national salary structure. Salaries of local government staff are paid from grants from the central government.

\section{Limited career opportunities}

The career paths of local government staff are limited compared to those of central government staff. Rigid local government structures limit promotion to a few levels. This limits career progression of staff. Hence, local government staff stays in the same position and at the same level for many years. Due to limited opportunities for career advancement, local government staff who wish to progress in their career, transfer to the central government or the private sector.

\section{Location of some districts}

Under Circular Standing Instruction No. 2 of 2010, the Ministry of Public Service (MoPS) designated 24 out of 112 districts in Uganda as 'hard-to-reach'. The concept encompasses the elements of being hard to stay and work in. Other dimensions of hard to reach include remoteness, insecurity and poor infrastructure. The remote nature of districts and poor road quality makes make access to/from the district time-consuming and challenging. On top of being hard to reach, internet and power are frequently unstable and susceptible to prolonged outages. The nature of these districts dissuades 
individuals from taking posts outside of urban areas and/or leads to staff retention problems. These local governments have consistently failed to attract and retain skilled and competent personnel, leading to gaps and inadequacies in the delivery of services (MoPS, 2010). To attract and retain staff in hard to reach areas, a 'hard-to-reach framework’ comprising of short-term, long-term and long-term interventions. The strategies include payment of a hardship allowance (30\% of the basic monthly salary), leave transport concession, transport allowance and provision of preferential training and career growth support, as well as targeted recruitment, construction of staff housing, improved planning of public investments, pay reform strategies, improvement of general infrastructure and sector specific initiatives. From July 2010, the government implemented two interventions: payment of hardship allowance and improvement of infrastructure in health facilities and schools. Under the implementation of modalities, payment of hardship allowance excludes public officers working in municipalities, town councils and headquarters of designated local governments. The efficacy of the two interventions is not yet known.

\section{Conclusions}

Uganda's experience with the separate personnel system for local government, leads to the following conclusions.

i. The way that a local government recruitment agency is constituted significantly influences how it acts. Evidence from Uganda lends credence to this proposition. DSCs that are constituted on narrow interests will be predisposed to serve narrow interests (serving interests of the appointing authority and not serving the interests of the district). Equally worth noting, a local government recruitment agency that is appointed in breach of merit principles is unlikely to appoint civil servants on merit. Given the relationship between merit appointment and service delivery, councils should appoint recruitment agencies on merit and DSCs should place the interests of the districts above those of individual council members.

ii. With decentralization by devolution, the gap between law/policy and practice in civil service management in sub-national governments is inevitable. In Uganda, for example, domestic laws (Constitution and Local Government Act) guarantee the independence of the DSCs and further require DSCs to appoint staff on merit. But there is evidence that the DSCs are sometimes influenced by their appointing authority (District Councils) and some appointments in the local government civil service are devoid of merit.

iii. Lack of merit-based civil service appointment undermines the capacity of the local government civil service to deliver services. 
iv. Decentralization by devolution and consequent decentralization of human resources may be construed as localisation of the labour market by recruitment agencies and elected leaders in local governments. This leads to the syndrome of 'sons and daughters of the soil'.

v. Local governments formed along ethnic lines heighten patronage and tribalism in recruitment and selection. This may undermine national unity.

vi. Design of decentralization programmes should take into account the potential effects of patronage in procuring human resources. Decentralization heightens the politics in civil service management.

vii. The short and renewable term of office for members of recruitment agencies breeds opportunities for local politicians to influence their selection decisions.

viii. Limited career opportunities for local government staff, coupled with low pay, militates against attraction and retention of qualified staff.

ix. The location of local governments affects their capacity to attract and retain quality staff to deliver mandated services and this leads to gaps in delivery of services.

x. Retention of civil servants is integral to the performance of local governments.

\section{Recommendations and policy issues}

From the above conclusions, the following recommendations can be made.

Government should fix the pay problem in the public service to enable local governments attract and retain the human resource needed to deliver the decentralized services.

- Central government should emphasise merit-based appointment as part of a national development strategy aimed at economic growth and equity. This could be achieved through:

- Making it mandatory for central service commissions (Public Service Commission, Education Service Commission and Health Service Commission) to be involved in recruitment of middle and senior local government officials (those from U4 to U1E salary scales) falling within their sectors rather than the current requirement of only using guidelines from the central service commissions. Guidelines are necessary but not sufficient to guarantee compliance with them. 
- Introducing selection tests/examinations to complement oral interviews in selection. Owing to limited capacity of local governments in designing selection tests, the Selection Systems Department of the Public Service Commission should be mandated to set, administer and mark the tests.

- $\quad$ Enhancing appreciation by politicians, members of the DSCs and the general public of meritbased recruitment principles through training and sensitization.

- Amending the Local Government Act to provide for a single and longer term of office for members of the DSC.

- Strengthening compliance inspection of DSCs by the Ministry of Local Government and the Public Service Commission.

- $\quad$ Sacking and prosecuting members of DSCs that breach minimum recruitment standards and engage in other irregularities. The current practice of IGG and PSC ordering DSCs to rescind irregular appointments does not act as a deterrent.

- $\quad$ Attractive conditions of employment should be designed for staff of local governments in hard to reach areas.

\section{Concluding remarks}

In this paper, I have tried to demonstrate the implications of decentralization for civil service management, and the extent to which civil service issues impact on the effectiveness of decentralization. Unless civil service issues are addressed, the efficacy of decentralization will be undermined. Despite a range of civil service management issues that have been raised in the paper, the separate personnel system is the most appropriate personnel arrangement for local governments under decentralization by devolution. The alternative personnel arrangements tend to be viewed by local governments with a high degree of scepticism. In fact local governments may perceive staff operating under integrated or unified systems as having been imposed on them. In such systems, 'you are not our employee' attitude on the part of local elected leaders cannot be avoided. Hence, policy makers should mainly focus on fixing the challenges being experienced by local governments under a separate personnel system. There is truism in the statement that a problem is solved by identifying the forces that sustain it and accordingly weakening them. In this regard, policy makers need to identify the context specific factors that account for patronage in civil service appointments and failure by local governments to attract staff and accordingly weaken them. Continued appointment of staff based on patronage networks and huge staffing gaps in local governments definitely affect the effectiveness 
of decentralization. National development visions are likely to elude African countries unless meritbased appointment is emphasised and staffing challenges are addressed.

\section{References}

Amooti, K. (2010) The Challenges of Socio - Economic Infrastructure Development in Local Governments. Paper presented at the Joint Annual Review of Decentralization (JARD 2010) on $13^{\text {th }}$ January 2011, Kampala, Uganda

Aslam G, Yilmaz, S \& Gurkan, A. (2010) A Framework to Assess Administrative Decentralization. Community Driven Development and Local Governance, Issue no. 129/June 2010

Bossert T.J. \& Beauvais,J. (2002) Decentralization of Health Systems in Ghana, Zambia, Uganda and the Philippines: A Comparative Analysis of Decision Space, Health Policy and Planning 17(1),14-31

Galiwango, W.H. (2008) Decentralization and Development: The contradictions of local governance in Uganda with specific reference to Masindi and Sembabule districts. Unpublished PhD thesis, Nelson Mandela Metropolitan University, South Africa

GoU (1995) Constitution of the Republic of Uganda, 1995. GoU (Government of Uganda) Kampala: Uganda Printing and Publishing Corporation

GoU (1997) Local Government Act (Cap 243). GoU (Government of Uganda) Kampala: Uganda Printing and Publishing Corporation

Green, A. (2005) 'Managing Human Resources in a Decentralized Context'.In East Asia Decentralizes: Making Local Governments Work, World Bank, Washington DC, , pp 129-153

IGG (2008) Final Report of the Third National Integrity Survey, Kampala: IGG (Inspectorate of Government)

Jean S. Lee T. Malarkey K \& McMahon, J.(2010) Local Government Fiscal Discretion in Uganda. Robert Wagner School of Public Service: New York

Kakumba U (2008) External control systems of accountability in Local Governments: the case of Uganda. Unpublished PhD thesis, University of Pretoria, South Africa

Kakumba U.( 2003) The Challenges of Personnel Decentralization and Local Government

Performance in Uganda: The Case of Luwero District. Unpublished Masters’ degree dissertation, Makerere University, Kampala, Uganda

Lubanga F.X. (1998) Human Resource Management and Development in the Context of Decentralization. In: A Nsibambi(Ed) Decentralization and Civil Society in Uganda: the Quest for Good Governance. Kampala: Fountain Publishers

Maheshwari, S.R. (2011) Personnel Administration in Urban Local Bodies in India: A Study. International Referred Research Journal, 3(27), 54-55

Manyak, T.G, \& Katono, I.W. (2010) Decentralization and Conflict in Uganda. African Studies Quarterly 11 (4), 1-24

Mawhood, P. (1983) Local Government in the Third World: The Experience of Tropical Africa. New York: Wiley

McCourt, W. (2007) The Merit System and Integrity in the Public Service, Public Integrity and Anti-corruption in the Public Service Conference, Bucharest, 29-30 May 2007. Available at http://www.oecd.org/dataoecd/27/51/39254857.pdf (accessed on 10 May 2010) 
Ministry of Local Government. (2010) Ministerial Policy Statement for 2010/2011 Financial Year. Kampala, Uganda

Ministry of Public Service (2003) A Report on the Review and Restructuring of Local Governments and Staffing Levels. Kampala: International Development Consultants

Ministry of Public Service. (2010) Circular Standing instruction No.2 of 2010: Payment of the Hardship allowance in the Public Service. Available at http://www.publicservice.go.ug (accessed on 28 June 2010)

Ndegwa,S \& Levy, B. (2003) The Politics of Decentralization in Africa: A Comparative Analysis. Paper presented at the Regional Workshop on Governance and Public Management, June 9-11, Johannesburg, South Africa

Nsibambi, A. (Ed). (1998) Decentralization and Civil Society in Uganda: the Quest for Good Governance. Kampala: Fountain Publishers

Olowu, D. (2001) Decentralization Policies and Practices under Structural Adjustment and Democratization in Africa. Democracy, Governance and Human Rights Programme Paper Number 4 July 2001, UNRISD

Peters, B.G. (2001) The Politics of Bureaucracy, 5th ed. London: Routledge

Raunch, J \& Evans. P. (2000) Bureaucratic Structure and Bureaucratic Performance in Less Developed Countries, Public Economics, 75, 49-71

Steffensen, J., Tidemand, P., Noitore, H., \& Mwaipopo, E.(2004). A Comparative Analysis of the Experiences of Decentralization in Kenya, Tanzania and Uganda, Available at www.dege.biz/FINALSYNTHESISREPORTnovember.pdf, (accessed on 23 May 2010)

Sharma, K.C. (2010) Role of local government in Botswana for effective service delivery: Challenges, prospects and lessons, Commonwealth Journal of Local Governance, 6,135-142

The New Vision. (2010) Public Service Commission Cancels Abim DEO Appointment. New Vision, 22 April 2010: 7, Kampala: New Vision Printing and Publishing Corporation

The New Vision (2010) IGG Accuses Amuru Officials of Bribery. New Vision, 1 April 2010: 7, Kampala: New Vision Printing and Publishing Corporation

The New Vision. (2010) Public Service Commission Axes Five Mukono Officials. New Vision, 31 May 2010: 8, the New Vision Printing and Publishing Corporation, Kampala, Uganda

The Daily Monitor.(2010) IGG orders sacking of Wobulenzi Town Clerk. The Daily Monitor, 19 March 2010:9, Kampala: Monitor Publications

Therkildsen, O \& Tidemand, P. (2007) Staff Management and Organisational Performance in Uganda and Tanzania. Copenhagen: Danish Institute for International Studies

United Nations. (2005) World Public Sector Report: Unlocking the Human Potential for Public Sector Performance. New York: United Nations

World Bank .(1997) Helping Countries Combat Corruption: The Role of the World Bank. Washington DC: The World Bank.

World Bank. (2003) Cambodia: Enhancing Service Delivery through Improved Resource Allocation and Institutional Reform. Integrated Fiduciary Assessment and Public Expenditure Review. Washington DC: World Bank

World Bank. (2008) Local Government Discretion and Accountability: A Local Governance Framework. Economic and Sector Work Report No. 41053. Washington DC: World Bank 
World Bank. (2009) Local Government Discretion and Accountability: Application of a Local Governance Framework. Economic and Sector World Report No. 49059-GLB, Social Development Department, Washington DC: World Bank 